\title{
Vitamin D in Chronic Kidney Disease and Dialysis Patients
}

\author{
Guillaume Jean ${ }^{1, *}$, Jean Claude Souberbielle ${ }^{2}$ and Charles Chazot ${ }^{1,3}$ \\ 1 NephroCare Tassin Charcot, Sainte Foy les Lyon, 69110, France; chchazot@gmail.com \\ 2 Service d'explorations fonctionnelles, Hôpital Necker-Enfants malades, AP-HP, Paris 75015, France; \\ jean-claude.souberbielle@aphp.fr \\ 3 F-CRIN, Investigation Network Initiative-Cardiovascular and Renal Clinical Trialist, \\ Vandoeuvre-lès-Nancy 54500, France \\ * Correspondence: guillaume-jean-crat@wanadoo.fr; Tel.: +33-472-323-124
}

Received: 2 February 2017; Accepted: 20 March 2017; Published: 25 March 2017

\begin{abstract}
Vitamin D deficiency $(<20 \mathrm{ng} / \mathrm{mL})$ and insufficiency $(20-29 \mathrm{ng} / \mathrm{mL})$ are common among patients with chronic kidney disease (CKD) or undergoing dialysis. In addition to nutritional and sunlight exposure deficits, factors that affect vitamin D deficiency include race, sex, age, obesity and impaired vitamin D synthesis and metabolism. Serum $1,25(\mathrm{OH})_{2} \mathrm{D}$ levels also decrease progressively because of $25(\mathrm{OH}) \mathrm{D}$ deficiency, together with impaired availability of $25(\mathrm{OH}) \mathrm{D}$ by renal proximal tubular cells, high fibroblast growth factor (FGF)-23 and decreased functional renal tissue. As in the general population, this condition is associated with increased morbidity and poor outcomes. Together with the progressive decline of serum calcitriol, vitamin D deficiency leads to secondary hyperparathyroidism (SHPT) and its complications, tertiary hyperparathyroidism and hypercalcemia, which require surgical parathyroidectomy or calcimimetics. Kidney Disease Outcomes Quality Initiative (KDOQI) and Kidney Disease Improving Global Outcomes (KDIGO) experts have recognized that vitamin D insufficiency and deficiency should be avoided in CKD and dialysis patients by using supplementation to prevent SHPT. Many vitamin D supplementation regimens using either ergocalciferol or cholecalciferol daily, weekly or monthly have been reported. The benefit of native vitamin $\mathrm{D}$ supplementation remains debatable because observational studies suggest that vitamin D receptor activator (VDRA) use is associated with better outcomes and it is more efficient for decreasing the serum parathormone (PTH) levels. Vitamin D has pleiotropic effects on the immune, cardiovascular and neurological systems and on antineoplastic activity. Extra-renal organs possess the enzymatic capacity to convert $25(\mathrm{OH}) \mathrm{D}$ to $1,25(\mathrm{OH})_{2} \mathrm{D}$. Despite many unanswered questions, much data support vitamin $\mathrm{D}$ use in renal patients. This article emphasizes the role of native vitamin D replacement during all-phases of CKD together with VDRA when SHPT persists.
\end{abstract}

Keywords: vitamin D; chronic kidney disease; dialysis; hyperparathyroidism; vitamin D receptor activators

\section{Background}

Vitamin D is a fat-soluble secosteroid that has a specific cytosolic receptor. This hormonal system is involved in the regulation of nearly $3 \%$ of the human genome. It was first known to play a central role in calcium and phosphate metabolism; however, more recently, vitamin D deficiency has been associated with numerous events and conditions in the general population such as falls, fractures, diabetes, autoimmune diseases, cardiovascular and renal diseases, tuberculosis, depression, neurodegenerative diseases, and cancer [1,2].

Humans acquire the majority of their vitamin D from sunlight-induced cutaneous synthesis, (approximatively $80 \%$ ), the rest comes from diet and supplement [1]. Vegetable sources provide 
ergocalciferol $\left(D_{2}\right)$ and animal sources provide cholecalciferol $\left(D_{3}\right)$; both of these have similar metabolisms. These precursors are transported in the liver by a vitamin D binding protein (DBP); then, vitamin $\mathrm{D}$ is hydroxylated at the $\mathrm{C} 25$ position by specific hydroxylase coded by the CYP2R1 gene. 25-hydroxyvitamin $\mathrm{D}(25(\mathrm{OH}) \mathrm{D})$ is the main circulating form of vitamin $\mathrm{D}$. It has been considered a precursor of the active form $1,25(\mathrm{OH})_{2} \mathrm{D}$, but, at very high concentration, it has the capacity to bind to vitamin D receptor (VDR). Furthermore, various extrarenal cells express megalin, particularly parathyroid cells and osteoblast, and the $1 \alpha$-hydroxylase [3]. Therefore, local production of $1,25\left(\mathrm{OH}_{2}\right) \mathrm{D}$ occurred in numerous tissues [4].

Some experts have defined vitamin D deficiency as a serum $25(\mathrm{OH}) \mathrm{D}$ level $<20 \mathrm{ng} / \mathrm{mL}$ and insufficiency as between 21 and $29 \mathrm{ng} / \mathrm{mL}$ : a target of $>30 \mathrm{ng} / \mathrm{mL}$ is suggested for optimal health $[1,5,6]$. However, this remains controversial because of the lack of a consensus regarding the optimal range for serum $25(\mathrm{OH}) \mathrm{D}[7,8]$. Nevertheless, there is a common understanding that low serum $25(\mathrm{OH}) \mathrm{D}$ levels cause a negative calcium balance, secondary hyperparathyroidism (SHPT), and bone disease.

Few foods contain sufficient vitamin D. Therefore, without daily sunlight exposure or fortified food, an important risk for vitamin D deficiency exists. Thus, climate, location, aging, lifestyle, and skin pigmentation affect vitamin $\mathrm{D}$ production.

The Workshop Consensus for Vitamin D Nutritional Guidelines estimated that more than $50 \%$ of the older population are vitamin D-deficient or vitamin D-insufficient [9]. The same is true for younger populations, even in sunny countries [10]. Therefore, more than one billion people are thought to have vitamin D insufficiency or deficiency worldwide.

In chronic kidney disease (CKD), the hyperphosphaturic osteocyte-derived hormone FGF-23 increases to compensate for phosphate retention and further inhibits renal $1 \alpha$-hydroxylase expression, and induces the expression of 24-hydroxylase responsible for the degradation of 1,25- $\left(\mathrm{OH}_{2}\right) \mathrm{D}$. However, $24,25(\mathrm{OH}) \mathrm{D}$ levels are lower in dialysis patients than in the normal population. Thus, the impaired uptake of $25(\mathrm{OH}) \mathrm{D}$ by altered kidneys remains the main cause of $1,25\left(\mathrm{OH}_{2}\right) \mathrm{D}$ deficiency [11] since the metabolic clearance rate of calcitriol seems not altered [12]. In addition to the direct effect of high $25(\mathrm{OH}) \mathrm{D}$ levels, local osteoblastic conversion of $25(\mathrm{OH}) \mathrm{D}$ to $1,25\left(\mathrm{OH}_{2}\right) \mathrm{D}$ appears to be an important positive regulator of FGF-23 production, particularly in uremia [13].

Together with decreased kidney function, a decrease in $1,25(\mathrm{OH})_{2} \mathrm{D}$ leads to hypocalcemia and SHPT, which are the main causes of secondary osteoporosis.

The risk for falls and fracture is four times greater for female dialysis patients compared with the general population [14], and this could justify prevention strategies. Evidence for the usefulness of vitamin $\mathrm{D}$ to treat renal bone disease is now nearly six decades old. However, the routine use of vitamin $\mathrm{D}$ for preventing or reversing the impact of SHPT on the bones of patients with CKD has been implemented in regular clinical practice for only three decades. During the initial years of dialysis use, native vitamin D compounds (calciferol and calcidiol) were prescribed [15]. In the 1980s, active vitamin $\mathrm{D}$ compounds were identified and were used instead [16]. This transition could be explained by the fact that it was assumed that $25(\mathrm{OH}) \mathrm{D}$ could not be metabolized to $1,25(\mathrm{OH})_{2} \mathrm{D}$ by the kidneys. However, the pharmacological impacts of different vitamin D species and of their different modes of administration cannot be assumed to be uniform across the spectrum.

Both the Kidney Disease Outcomes Quality Initiative (KDOQI) [5] and Kidney Disease Improving Global Outcomes (KDIGO) [17] experts recommend checking and supplementing low serum 25(OH)D levels in CKD and dialysis patients.

The aim of this review was to provide the current actual knowledge and to address the questions nephrologists may have regarding vitamin $\mathrm{D}$ in CKD and dialysis patients.

\section{Why Are Low Serum 25(OH)D Levels Generally Observed in CKD and Dialysis Patients?}

CKD represents one of the main conditions associated with low $25(\mathrm{OH}) \mathrm{D}$ serum levels. Studies of transplant recipients showed a high frequency of vitamin $\mathrm{D}$ insufficiency ( $>80 \%$ of cases) [18]. The same is true for CKD non-transplant patients, with $>80 \%$ having low serum $25(\mathrm{OH}) \mathrm{D}$ levels [19]. 
Observational studies reported progressive vitamin D deficiency worsening from stage 3 to stage 5D [20]. However, in a cross-sectional study, Guesseous et al. reported that vitamin D deficiency is similarly observed in CKD patients and in the general population [21]. The main causes and risk factors for vitamin D deficiency and insufficiency are displayed in Table 1. In addition, age and female sex, proteinuria, low physical activity [22], diabetes [23], and body adiposity [24] are associated with vitamin D deficiency in CKD patients. Cankaya et al. reported that serum vitamin D level is lower in peritoneal dialysis (PD) and hemodialysis (HD) patients compared with CKD and renal transplant patients [25].

Table 1. Causes and risk factors for 25(OH)D deficiency or insufficiency in CKD and dialysis patients.

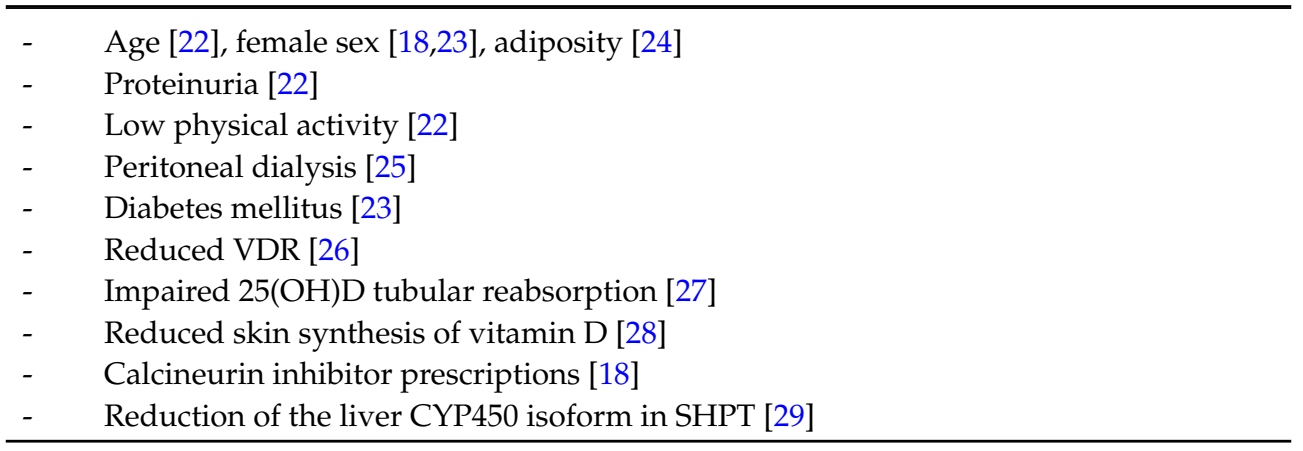

Jacob et al. reported that chronic hemodialysis patients exhibit defective photoproduction of cholecalciferol, despite normal epidermal content of substrate, 7-dehydrocholesterol [28].

In transplant recipients, the same factors are found together with the risk identified when prescribing calcineurin inhibitors treatments [18].

VDR levels are reduced and CYP24A1 is increased in CKD patients [26]. In addition, vitamin $\mathrm{D}$ binding protein (VDBP) seems to increase and is not involved in $25(\mathrm{OH}) \mathrm{D}$ deficiency in CKD patients [30]. Takemoto et al. reported that $25(\mathrm{OH}) \mathrm{D}$ tubular reabsorption is impaired due to decreased renal megalin [27]. As a compensatory mechanism, vitamin D catabolism, measured by $24,25(\mathrm{OH})_{2} \mathrm{D}$, is decreased in CKD patients and especially in dialysis patients [31]. Michaud et al. suggested that uremia decreases $25(\mathrm{OH}) \mathrm{D}$ synthesis secondary to PTH-mediated reduction in liver CYP450 isoforms [29]. Therefore, it could be speculated a vicious cycle involving vitamin D and SHPT that requires progressive amounts of vitamin $\mathrm{D}$ compounds to be reversed.

\section{Consequences of Low Serum 25(OH)D Levels in CKD and Dialysis Patients}

The associations between vitamin D deficiency and insufficiency and symptoms or outcomes are reported in Table 2.

Table 2. Association between vitamin D deficiency or insufficiency and outcomes for CKD and Dialysis populations.

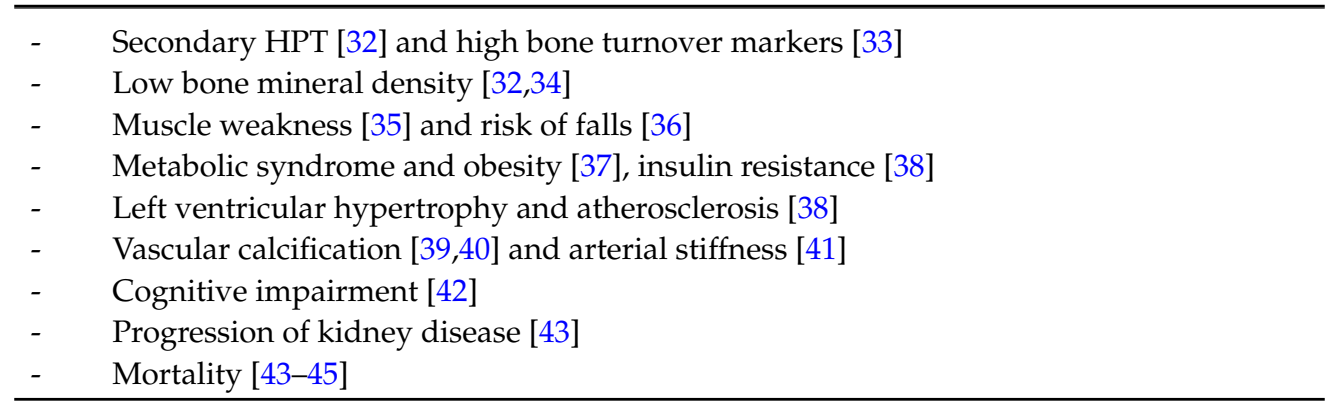


Low $25(\mathrm{OH}) \mathrm{D}$ has been associated with high bone turnover, SHPT, and decreased bone mineral density (BMD) in CKD and dialysis patients [32-34]. Low 25(OH)D has been associated with muscle weakness [35] and risk of falls [36]. Boudville et al. reported that $25(\mathrm{OH}) \mathrm{D}$ deficiency is associated with muscular weakness and falls in dialysis patients, but with a J curve and maximal benefit in the range between 24 and $44 \mathrm{ng} / \mathrm{mL}$ of serum 25(OH)D levels [36]. Vitamin D deficiency has been associated with metabolic syndrome and obesity [37] in HD patients. In PD patients, low vitamin $\mathrm{D}$ levels have been associated with cognitive impairment [42]. In transplant recipients, low serum $25(\mathrm{OH}) \mathrm{D}$ level is associated with a rapid decline in renal function [46,47]. Vitamin D deficiency has been associated with insulin resistance, ventricular hypertrophy, atherosclerotic disease [38], and vascular calcifications [39]. London et al. reported an inverse relationship between arterial stiffness and serum $25(\mathrm{OH}) \mathrm{D}$ and $1,25(\mathrm{OH})_{2}$ D levels in dialysis patients [41]. Ravani et al. reported that serum $25(\mathrm{OH}) \mathrm{D}$ levels $<15 \mathrm{ng} / \mathrm{mL}$ are associated with both the risk for mortality and progression to dialysis in predialysis CKD patients [43]. A resistance to vitamin $\mathrm{D}_{3}$ has been reported in CKD and is associated with progression of renal disease [48]. Besides, the defects in calcitriol upregulation of renal Klotho expression may play a role in the progression of renal damage and cardiovascular disease in CKD patients $[49,50]$.

The renal protective effect of vitamin $D$ has been linked with inhibition of the renin-angiotensin system and NF- $\mathrm{kB}$ pathway [51] and upregulation of nitric oxide synthase transcription in vascular endothelial cells [52].

In a meta-analysis [44], Pilz et al. reported that $10 \mathrm{ng} / \mathrm{mL}$ higher 25(OH)D level was associated with a decrease of $14 \%$ in mortality risk. The prognosis of CKD patients seems to improve with vitamin D supplementation [53]. Low $1,25(\mathrm{OH})_{2} \mathrm{D}$ [54] and low 25(OH)D [45] have been associated with mortality in dialysis patients. In some dialysis cohorts, a clear association between low serum 25(OH)D levels and mortality has been reported. For example, in a French cohort, mortality risk was increased by $30 \%$ when the serum $25(\mathrm{OH}) \mathrm{D}$ level was $<18 \mathrm{ng} / \mathrm{mL}$ [45]. However, the relationship between outcomes and serum $25(\mathrm{OH}) \mathrm{D}$ level should be interpreted together with serum PTH and FGF-23 [55].

\section{How Can Vitamin D Deficiency and Insufficiency Be Supplemented?}

Because of the long life of complex 25(OH)D and DBP $(480 \mathrm{~h})$, daily $\left(1000 \mathrm{U} \mathrm{D}_{3}\right)$, weekly [56] or monthly $\left(40,000 \mathrm{U} \mathrm{D}_{3}\right)$ [57] regimens seem efficient for restoring $25(\mathrm{OH}) \mathrm{D}$ levels [58]. For years, we chose to provide monthly cholecalciferol during dialysis to insure observance [59]. Zitt et al. reported that a weekly dosing regimen of $100 \mathrm{U} / \mathrm{kg}$ body weight for dialysis patients allows achievement of target serum $25(\mathrm{OH}) \mathrm{D}$ level in only $27 \%$ of cases [60]. Vitamin D provided during dialysis is more effective than home prescriptions [61]. Calcifediol is sometimes prescribed as daily, biweekly, or monthly vitamin D supplementation with the same efficiency [62]. In France, nephrologists used to prescribe cholecalciferol as oral 100,000 IU monthly doses, which allow normalization of serum $25(\mathrm{OH}) \mathrm{D}$ level in $>85 \%$ of cases [59]. In Belgium, Delanaye et al. reported their experience using oral cholecalciferol 25,000 IU every two weeks, which allowed achievement of the recommended targets of $>30 \mathrm{ng} / \mathrm{mL}$ after 12 months [63].

In CKD non-dialysis patients, this is not usually necessary, as according to our experience, $50,000 \mathrm{IU}$ of cholecalciferol monthly is sufficient in most cases.

Even though these protocols demonstrated their efficiency, safety and simplicity, others can be used after validation with serum 25(OH)D, PTH, calcium, and phosphate levels.

Protocols using initially high loading doses and subsequent low dose displayed less efficiency and the risk for over dosing during the first weeks and under dosing thereafter has been reported $[64,65]$.

It must be noted that the pharmaceutical vitamin $\mathrm{D}_{3}$ dosages that are available greatly differ from one country to another. In France, only drops (300 IU/drop) or calcium + vitamin $\mathrm{D}_{3}$ combinations are available for daily supplementation, while $80,000,100,000$ and 200,000 IU vials are available as spaced-out doses. This is the reason why monthly doses are most often prescribed in France. However, 
a recent meta-analysis of randomized controlled trials (RCTs) has shown that daily (or weekly) vitamin $\mathrm{D}_{3}$ doses are more efficient to reduce acute respiratory tract infections than monthly doses [66]. Several vitamin $\mathrm{D}$ experts have provided reasons why daily dosing is much better than bolus dosing $[67,68]$, explaining why many of the trials that used bolus doses resulted in negative findings. Furthermore, while daily doses of 700-1000 IU/day reduce the risk of falls [69] and fractures [70] in the elderly, it was found in a RCT published in 2010 that elderly women who received a very large annual dose of 500,000 IU had more falls than those who received the placebo [71]. Recently, Bischoff-Ferrari et al. have shown in a RCT that frail elderly patients who received monthly doses of $60,000 \mathrm{IU}$ (equivalent to $2000 \mathrm{IU} /$ day) during one year sustained significantly more falls than other patients who were randomized to 24,000 IU per month (equivalent to $800 \mathrm{IU} /$ day) [72]. As the same authors previously found no difference in terms of falls between women who received $800 \mathrm{IU} /$ day or $2000 \mathrm{IU} /$ day [73], their recent results suggest that higher monthly doses are more deleterious than beneficial for the risk of falls compared to moderate ones. Although such data do not exist in CKD patients treated or not treated by chronic dialysis, we take the above-mentioned results into account and we expect that daily vitamin $\mathrm{D}_{3}$ doses that are more suitable for clinical use than those currently available will be introduced in France in the near future.

\section{Effect of Native Vitamin D Supplementation on CKD and Dialysis Patients}

The main reported effects of vitamin D supplementation are displayed in Table 3. These effects depend on the vitamin D dosage, the type of vitamin D compounds, the duration of the study, and the studied population. One of the main expected effects is the lowering of serum PTH level. Hence, the results are not always positive. In a meta-analysis, Kandula et al. reported that nutritional vitamin D leads to increased 25(OH)D levels (mean $+24 \mathrm{ng} / \mathrm{mL}$ ) without any hypercalcemia or hyperphosphatemia and with a decrease in serum PTH level (41\% decrease), mostly in dialysis patients [74]. The mean dosage was 50,000 IU weekly during the first month; a lower dosage was used thereafter. Cupisti et al. and Alvarez et al. [75] reported mildly reduced serum PTH levels after vitamin D supplementation [76]. We have reported a decrease in SHPT in dialysis patients after systematic vitamin D supplementation during the predialysis period [77]. Novel modified-release calcifediol seems to have significant efficacy in decreasing PTH in CKD patients [78]. A recent randomized controlled trial (RCT) assessing short-term effects of ergocalciferol, weekly or monthly, during three months, failed to find a significant effect on PTH level [79]. However, comparing the different published regimens, Tangpricha et al. suggested that insufficient dosages (i.e., $<100,000 \mathrm{U} /$ month) may not be sufficient to achieve adequate replenishment, increased $1,25(\mathrm{OH})_{2} \mathrm{D}$ and decreased PTH [80]. We need to determine the dose range for responsiveness using ergocalciferol or cholecalciferol and different protocols (daily, weekly, or monthly administration). However, due to its shorter high life, ergocalciferol should not be prescribed on a monthly regimen. Massart et al. [56] and we [59] reported increased serum $1,25(\mathrm{OH})_{2} \mathrm{D}$ level after cholecalciferol supplementation. Seibeirt et al. confirmed these data and additionally did not find an increase in FGF-23 concentration after vitamin D supplementation [81].

Table 3. Reported effects of vitamin D supplementation on CKD and dialysis patients.

\begin{tabular}{ll}
\hline- & Serum PTH level decrease $[74-76,78]$ \\
- & Serum $1,25(\mathrm{OH})_{2}$ D level increase $[56,59,81]$ \\
- & Reduced proteinuria [82] \\
- & Endothelial cardiovascular markers improvement $[83]$ \\
- & Inflammation markers decrease [84] \\
\hline
\end{tabular}

Aytac et al. reported a favorable effect of high-dose cholecalciferol on cardiovascular and endothelial parameters of children with CKD [83] by using flow-mediated dilatation, arterial stiffness, homocysteine, and von Willebrand factor measurements. Karakas et al. confirmed that eight weeks of 
cholecalciferol improved the percentage of flow-mediated dilatation in dialysis with CKD patients [85]. In diabetic non-dialyzed patients using angiotensin-converting enzyme inhibitors, a decrease in proteinuria by adding native vitamin $\mathrm{D}$ was found by Kim et al. [82]. Meireless et al. reported in a RCT that cholecalciferol (50,000 twice weekly) promoted upregulation of CYP27B1 and VDR expression in monocytes and decreased serum IL-6 and C-reactive protein levels [84]. In a recent meta-analysis, Mann et al. reported a lack of significant effects of vitamin D supplementation on mortality [86].

Results of vitamin D trials vary for the general population and renal patients. The discrepancies may be due to differences in baseline serum $25(\mathrm{OH}) \mathrm{D}$ levels, vitamin D doses and treatment periods, adherence to supplementation, and VDR genetic polymorphisms [87].

\section{Vitamin D Toxicity?}

Opposite to vitamin D receptor activator (VDRA), nutritional vitamin D compounds are unlikely to induce hypercalcemia using a normal regimen because its $1 \alpha$-hydroxylase activation is regulated by PTH, FGF-23 and 24-hydroxylase.Therefore, a serum 25(OH)D level up to $100 \mathrm{ng} / \mathrm{mL}$ is considered safe [1]. In the general population, daily vitamin D intakes $>10,000$ IU may be toxic because they lead to DBP saturation with an increase of free serum 25(OH)D [88]. In addition, toxicity has been observed for higher dosages ( $>40,000 \mathrm{U} /$ day) [89]. Jacobus et al. reported eight cases of vitamin D intoxication that appear to have been caused by excessive vitamin $\mathrm{D}$ fortification of dairy milk with serum 25(OH)D $>300 \mathrm{ng} / \mathrm{mL}$ [90].

Vitamin D toxicity is increased by higher calcium intake, calcitriol analogs, and adynamic bone disease in dialysis patients. The frequency of this toxicity is not known but appears very rare. Diagnosis mainly includes hypercalcemia with the risk for extraosseous calcification. Hypercalciuria is not frequently observed because calciuria is very low in CKD and dialysis patients. The native vitamin D compounds' half-life is very long, approximatively two weeks, and toxicity should be treated for weeks. The physiopathology of hypercalcemia includes higher $1,25(\mathrm{OH})_{2} \mathrm{D}$ synthesis, higher intestinal absorption of calcium, and higher calcium release from bone. Close biological monitoring (serum PTH, calcium and phosphate levels), at least in dialysis patients, could prevent vitamin D toxicity.

\section{Vitamin $\mathrm{D}_{2}$ or $\mathrm{D}_{3}$ ?}

In 2008, Cavalier et al. reported some problems with $25(\mathrm{OH}) \mathrm{D}$ assays when measuring $25(\mathrm{OH}) \mathrm{D}_{2}$ [91]. These problems are now solved. Armas et al. reported that ergocalciferol displays a shorter half-life and is less potent compared with cholecalciferol with the same initial peak, but the serum $25(\mathrm{OH}) \mathrm{D}$ plateau decreased quickly after a few days using $\mathrm{D}_{2}$ and lasting 14 days using $\mathrm{D}_{3}$ [92]. Holick et al. showed that $\mathrm{D}_{2}$ and $\mathrm{D}_{3}$, given as daily doses, display the same efficiency in increasing serum 25(OH)D levels [93]. However, Oliveri et al., using the same loading and daily dose, report a superiority for D3 compounds [94].

More recently, Wetmore et al. reported that therapy with cholecalciferol, compared with ergocalciferol, is more effective at raising serum $25(\mathrm{OH}) \mathrm{D}$ in non-dialysis-dependent CKD patients using the same dosage (50,000 IU weekly) [95]. Lehmann et al. reported that vitamin $\mathrm{D}_{3}$ increases the total $25(\mathrm{OH}) \mathrm{D}$ concentration more than vitamin $\mathrm{D}_{2}$ and vitamin $\mathrm{D}_{2}$ supplementation was associated with a decrease in $25(\mathrm{OH}) \mathrm{D}_{3}$, which can explain the different effect on total $25(\mathrm{OH}) \mathrm{D}$ [96].

Ergocalciferol is mostly used in the United States. In other countries, such as France, cholecalciferol is the standard form, at least for CKD patients. For dialysis patients, we currently use 100,000 IU of oral cholecalciferol monthly.

\section{VDRA for CKD and Dialysis Patients}

As reported since the 1970s and mostly the 1980s, calcitriol is efficient for treating SHPT with a $50 \%$ decrease in baseline serum PTH values [16,97]. Even though cinacalcet is a commonly used therapy for resistant SHPT, calcitriol and analogs (which are VDRAs) remain the first-line therapy. VDRAs are very efficient in decreasing serum PTH level, but could lead to adynamic bone disease and risks for toxicity 
and hypercalcemia, as reported initially when the target serum PTH value was lower $[16,97]$. Toxicity risk is increased by higher dosages, concomitant prescriptions of oral calcium, high dialysate calcium concentrations $(>1.5 \mathrm{mmol} / \mathrm{L})$, and native vitamin D. Adynamic bone disease is suspected with low serum bone marker levels (bone-specific alkaline phosphatase). The consequences of hypercalcemia are well known and related to its cellular toxicity. This could justify close biological monitoring, especially when prescribing higher dosages. However, hypercalcemia and hyperphosphatemia are less frequent than in the 1980s because the serum PTH target has increased, from a normal value to two to nine times the upper limit of the assay, leading to reduce the VDRAs dosage. Prospective interpretation of serum PTH evolution is not easy, as when prescribing calcimimetics, and bone marker evolution could help with therapeutic adjustment.

It has been reported that oral bolus administration of VDRA three times weekly was more efficient than the intravenous route [98]. The intravenous route is much more expensive and should be used only when the oral route is not suitable, such as in the case of gastrointestinal malabsorption. Administration of calcitriol or analogs could be performed daily or using a bolus. It is most often administered three times weekly after dialysis. In France, the mean weekly dosage is $<3 \mu \mathrm{g}$ of alfacalcidol, which is equivalent to $1.5 \mu \mathrm{g}$ of calcitriol.

VDRAs are clearly complementary with calcimimetics treatment to prevent hypocalcemia and improve PTH lowering [99]. The initial choice between these two therapies depends mainly on calcemia. When hypercalcemia occurs, tertiary HPT is suspected and calcimimetics could be the initial choice. In other cases, VDRAs could be the first choice for treating SHPT. In some large cohorts, mainly in the United States, it has been shown that dialysis patients treated with VDRAs displayed better outcomes [100-103]. A meta-analysis reported better survival for both CKD and dialysis patients treated with VDRAs [104].

A non-randomized prospective study performed in Japan reported lower mortality rates for dialysis patients treated with alfacalcidol [105]. We reported the same survival advantage in a French cohort of dialysis patients treated with alfacalcidol [45]. We do not know if this survival advantage is related to higher serum $1,25(\mathrm{OH})_{2} \mathrm{D}$ levels. At the moment, no interventional study showed any survival advantage for CKD and dialysis patients using native vitamin D supplementation. Tanaka et al. reported that infection-related mortality in Japan is reduced in patients receiving VDRA mostly intravenously [106]. In a recent meta-analysis of CKD, Li et al. reported that VDRAs reduced the incidence of cardiovascular events and reduced proteinuria, but resulted in an increased probability of hypercalcemia when paricalcitol was used [107]. In an observational study performed in Japan, it was reported that VDRA prescriptions during the late stages of CKD are associated with fewer cardiovascular diseases during the early dialysis stage [108]. Survival analysis in some observational cohorts from North America show advantages for patients treated with a synthetic analog (Paricalcitol), which is thought to be less hypercalcemic than calcitriol [100,102]. However, during treatment of SHPT, biological consequences, hypercalcemia and hyperphosphatemia were not different between paricalcitol and alfacalcidol [109]. Low-dose cholecalciferol in vitamin D-deficient HD patients and paricalcitol in cases of persistent SHPT have been reported to be efficient and to have no side effects [110].

Lou et al. reported a synergistic in vitro effect of $25(\mathrm{OH}) \mathrm{D}_{3}$ with $1 \alpha, 25\left(\mathrm{OH}_{2}\right) \mathrm{D}_{3}$ in Cyp27b1(-/-) cells that demonstrates the agonistic action of 25(OH)D3 of VDR [111].

In a recent study, in rat with SHPT, the correction of vitamin D deficiency effectively reversed the resistance to paricalcitol induction of CCAAT/Enhancer-binding-protein $\beta$ (C/EBP- $\beta$ ) to suppress ADAM metallopeptidase domain 17 expression (also called tumor necrosis factor- $\alpha$-converting enzyme) and parathyroid gland enlargement, reducing PTH by 50\% [112].

Agarwal et al. recommend prescribing only VDRA because nutritional vitamin D did not treat SHPT or improve outcomes [113]. Zoccali et al. recently recommended that native compounds should not be prescribed to CKD patients treated with VDRA because there is no evidence indicating that native vitamin $\mathrm{D}$ has no biological effect beyond the calcitriol metabolite [114]. 
However, the correction of calcitriol deficiency to correct SHPT with VDRA does not correct nutritional vitamin D deficiency and all the health benefits of normal vitamin D status, unrelated to a calcitriol status, will not be provided.

\section{Our Main Message}

We think that native vitamin D supplementation should be the first line of therapy for SHPT prevention. The main reasons are summarized in Table 4, but once SHPT or tertiary hyperparathyroidism (HPT) is observed, adding VDRA and/or calcimimetics is justified. However, unanswered questions still exist (Table 5).

Table 4. Why use supplements for vitamin D deficiency or insufficiency for CKD and dialysis patients?

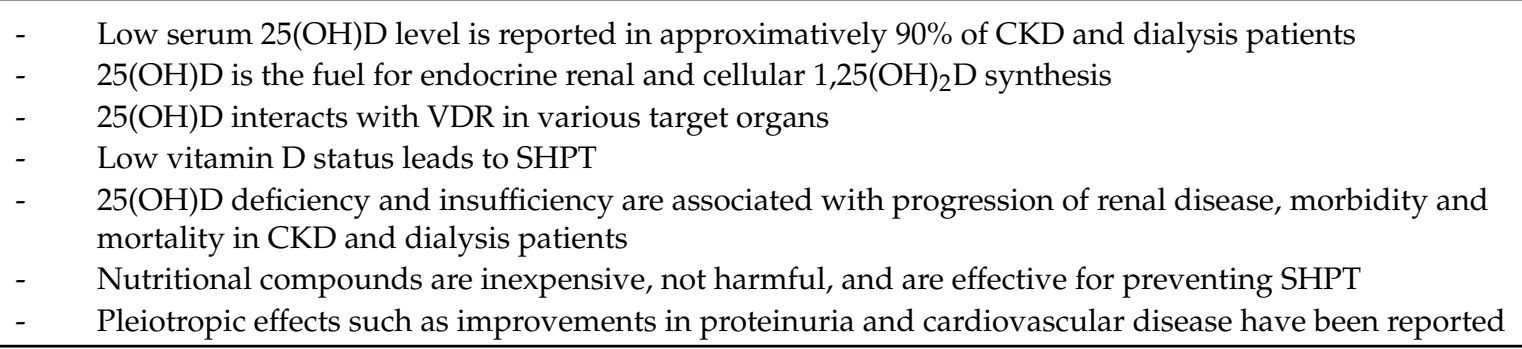

Table 5. Unanswered questions.

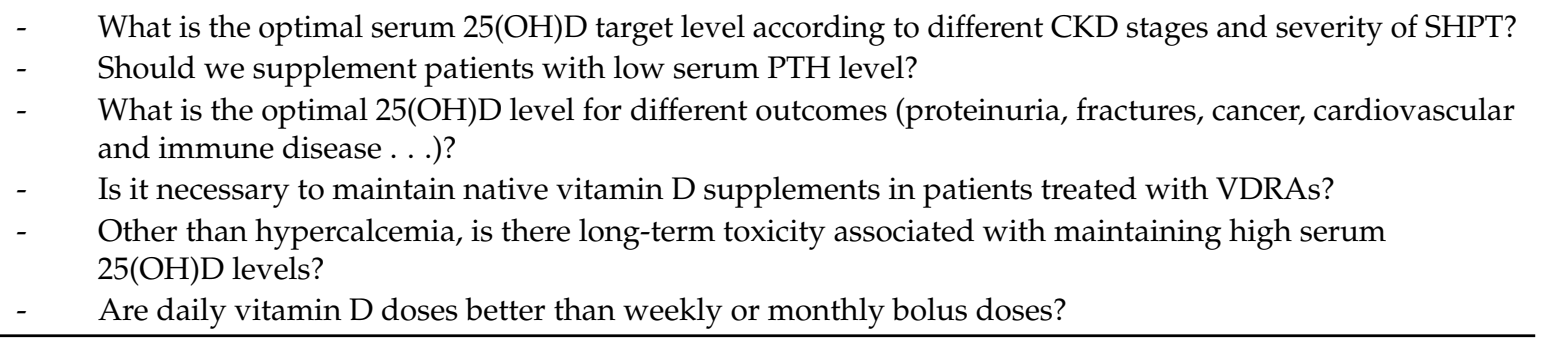

\section{Conclusions}

Vitamin D insufficiency, which involves both serum 25(OH)D and 1,25(OH)D levels, is generally observed in CKD and dialysis patients. The main consequence is SHPT, and vitamin D compounds remain the first-line therapy for its prevention and treatment.

Morbidity and mortality rates are associated with $25(\mathrm{OH}) \mathrm{D}$ insufficiency in CKD patients, but only VDRAs have been associated with better outcomes in large observational cohorts. Some questions remain unanswered about indication for serum vitamin $\mathrm{D}\left(25(\mathrm{OH}) \mathrm{D}\right.$ and $\left.1,25(\mathrm{OH})_{2} \mathrm{D}\right)$ measurements and about the real impact of these therapies on outcomes.

However, based on the recent published data, it appears justified to supplement CKD patients with 25(OH)D insufficiency and to use VDRAs for SHPT and hypocalcemia treatment. At last, large RCTs with clinically meaningful endpoints (fracture, hospitalization, parathyroidectomy, death) are still required to assess the usefulness of different vitamin D compounds for CKD and dialysis patients.

Author Contributions: Guillaume Jean has written the manuscript with the contribution of Jean-Claude Souberbielle. He has answered most of the issues raised by the reviewers. Jean-Claude Souberbielle actively contributed to answer the reviewers' comments and questions. Charles Chazot has revised the manuscript and corrected the proofs.

Conflicts of Interest: Guillaume Jean has received honoraria from Fresenius Medical Care; Jean Claude Souberbielle reports lecture fees and/or travel/hotel expenses from DiaSorin, Roche Diagnostics, Abbott, Amgen, Shire, MSD, Lilly, and MEDA. Charles Chazot is a Fresenius Medical Care employee. The authors declare no conflict of interest. 


\section{References}

1. Holick, M.F. Vitamin D deficiency. N. Engl. J. Med. 2007, 357, 266-281. [CrossRef] [PubMed]

2. Plum, L.A.; DeLuca, H.F. Vitamin D, disease and therapeutic opportunities. Nat. Rev. Drug Discov. 2010, 9, 941-955. [CrossRef] [PubMed]

3. Townsend, K.; Evans, K.N.; Campbell, M.J.; Colston, K.W.; Adams, J.S.; Hewison, M. Biological actions of extra-renal 25-hydroxyvitamin D-1alpha-hydroxylase and implications for chemoprevention and treatment. J. Steroid Biochem. Mol. Biol. 2005, 97, 103-109. [CrossRef] [PubMed]

4. Dusso, A.S.; Tokumoto, M. Defective renal maintenance of the vitamin D endocrine system impairs vitamin D renoprotection: A downward spiral in kidney disease. Kidney Int. 2011, 79, 715-729. [CrossRef] [PubMed]

5. Eknoyan, G.; Levin, A.; Levin, N.W. Bone metabolism and disease in chronic kidney disease. Am. J. Kidney Dis. 2003, 42, S1-S201. [CrossRef]

6. Souberbielle, J.C.; Body, J.J.; Lappe, J.M.; Plebani, M.; Shoenfeld, Y.; Wang, T.J.; Bischoff-Ferrari, H.A.; Cavalier, E.; Ebeling, P.R.; Fardellone, P.; et al. Vitamin D and musculoskeletal health, cardiovascular disease, autoimmunity and cancer: Recommendations for clinical practice. Autoimmun Rev. 2010, 9, 709-715. [CrossRef] [PubMed]

7. Manson, J.E.; Brannon, P.M.; Rosen, C.J.; Taylor, C.L. Vitamin D Deficiency-Is There Really a Pandemic? N. Engl. J. Med. 2016, 375, 1817-1820. [CrossRef] [PubMed]

8. Holick, M.F.; Binkley, N.C.; Bischoff-Ferrari, H.A.; Gordon, C.M.; Hanley, D.A.; Heaney, R.P.; Murad, M.H.; Weaver, C.M. Endocrine Society. Evaluation, treatment, and prevention of vitamin D deficiency: An Endocrine Society clinical practice guideline. J. Clini. Endocrinol. Metab. 2011, 96, 1911-1930. [CrossRef] [PubMed]

9. Henry, H.L.; Bouillon, R.; Norman, A.W.; Gallagher, J.C.; Lips, P.; Heaney, R.P.; Vieth, R.; Pettifor, J.M.; Dawson-Hughes, B.; Lamberg-Allardt, C.J.; et al. 14th Vitamin D Workshop consensus on vitamin D nutritional guidelines. J. Steroid Biochem. Mol. Biol. 2010, 121, 4-6. [CrossRef] [PubMed]

10. Kumar, J.; Muntner, P.; Kaskel, F.J.; Hailpern, S.M.; Melamed, M.L. Prevalence and associations of 25-hydroxyvitamin D deficiency in US children: NHANES 2001-2004. Pediatrics 2009, 124, e362-e370. [CrossRef] [PubMed]

11. Ishimura, E.; Nishizawa, Y.; Inaba, M.; Matsumoto, N.; Emoto, M.; Kawagishi, T.; Shoji, S.; Okuno, S.; Kim, M.; Miki, T.; et al. Serum levels of 1,25-dihydroxyvitamin D, 24,25-dihydroxyvitamin D, and 25-hydroxyvitamin $\mathrm{D}$ in nondialyzed patients with chronic renal failure. Kidney Int. 1999, 55, 1019-1027. [CrossRef] [PubMed]

12. Dusso, A.; Lopez-Hilker, S.; Lewis-Finch, J.; Grooms, P.; Brown, A.; Martin, K.; Slatopolsky, E. Metabolic clearance rate and production rate of calcitriol in uremia. Kidney Int. 1989, 35, 860-864. [CrossRef] [PubMed]

13. Nguyen-Yamamoto, L.; Karaplis, A.C.; St-Arnaud, R.; Goltzman, D. Fibroblast Growth Factor 23 Regulation by Systemic and Local Osteoblast-Synthesized 1,25-Dihydroxyvitamin D. J. Am. Soc. Nephrol. 2017, 28, 586-597. [CrossRef] [PubMed]

14. Alem, A.M.; Sherrard, D.J.; Gillen, D.L.; Weiss, N.S.; Beresford, S.A.; Heckbert, S.R.; Wong, C.; Stehman-Breen, C. Increased risk of hip fracture among patients with end-stage renal disease. Kidney Int. 2000, 58, 396-399. [CrossRef] [PubMed]

15. Kaye, M.; Chatterjee, G.; Cohen, G.F.; Borra, S.; Sagar, S. Arrest of hyperparathyroid bone disease by the use of dihydrotachysterol in patients undergoing chronic hemodialysis. Trans. Assoc. Am. Phys. 1970, 83, 245-253. [PubMed]

16. Slatopolsky, E.; Weerts, C.; Thielan, J.; Horst, R.; Harter, H.; Martin, K.J. Marked suppression of secondary hyperparathyroidism by intravenous administration of 1,25-dihydroxy-cholecalciferol in uremic patients. J. Clin. Investig. 1984, 74, 2136-2143. [CrossRef] [PubMed]

17. Kidney Disease: Improving Global Outcomes (KDIGO) CKD-MBD Work Group. KDIGO Clinical practice guideline for the diagnosis, evaluation, prevention, and treatment of Chronic Kidney Disease-Mineral and Bone disorder (CKD-MBD). Kidney Int. 2009, 76 (Suppl. S113), S1-S130.

18. Filipov, J.J.; Zlatkov, B.K.; Dimitrov, E.P.; Svinarov, D. Relationship between vitamin D status and immunosuppressive therapy in kidney transplant recipients. Biotechnol. Biotechnol. Equip. 2015, 29, 331-335. [CrossRef] [PubMed] 
19. Ngai, M.; Lin, V.; Wong, H.C.; Vathsala, A.; How, P. Vitamin D status and its association with mineral and bone disorder in a multi-ethnic chronic kidney disease population. Clin. Nephrol. 2014, 82, 231-239. [CrossRef] [PubMed]

20. Kim, S.M.; Choi, H.J.; Lee, J.P.; Kim, D.K.; Oh, Y.K.; Kim, Y.S.; Lim, C.S. Prevalence of vitamin D deficiency and effects of supplementation with cholecalciferol in patients with chronic kidney disease. J. Ren. Nutr. 2014, 24, 20-25. [CrossRef] [PubMed]

21. Guessous, I.; McClellan, W.; Kleinbaum, D.; Vaccarino, V.; Zoller, O.; Theler, J.M.; Paccaud, F.; Burnier, M.; Bochud, M. Comparisons of serum vitamin D levels, status, and determinants in populations with and without chronic kidney disease not requiring renal dialysis: A 24-h urine collection population-based study. J. Ren. Nutr. 2014, 24, 303-312. [CrossRef] [PubMed]

22. Caravaca-Fontan, F.; Gonzales-Candia, B.; Luna, E.; Caravaca, F. Relative importance of the determinants of serum levels of 25-hydroxy vitamin D in patients with chronic kidney disease. Nefrologia 2016, 36, 510-516. [CrossRef] [PubMed]

23. Mohiuddin, S.A.; Marie, M.; Ashraf, M.; Hussein, M.; Almalki, N. Is there an association between Vitamin D level and inflammatory markers in hemodialysis patients? A cross-sectional study. Saudi J. Kidney Dis. Transpl. 2016, 27, 460-466. [PubMed]

24. Silva, M.I.B.; Cavalieri, V.V.; Lemos, C.C.; Klein, M.R.; Bregman, R. Body adiposity predictors of vitamin D status in nondialyzed patients with chronic kidney disease: A cross-sectional analysis in a tropical climate city. Nutrition 2017, 33, 240-247. [CrossRef] [PubMed]

25. Cankaya, E.; Bilen, Y.; Keles, M.; Uyanik, A.; Akbas, M.; Gungor, A.; Arslan, S.; Aydinli, B. Comparison of Serum Vitamin D Levels Among Patients With Chronic Kidney Disease, Patients in Dialysis, and Renal Transplant Patients. Transpl. Proc. 2015, 47, 1405-1407. [CrossRef] [PubMed]

26. Ye, J.J.; Zhou, T.B.; Zhang, Y.F.; Wang, Q.; Su, Y.Y.; Tang, J.M.; Li, H.Y. Levels of vitamin D receptor and CYP24A1 in patients with end-stage renal disease. Afr. Health Sci. 2016, 16, 462-467. [CrossRef] [PubMed]

27. Takemoto, F.; Shinki, T.; Yokoyama, K.; Inokami, T.; Hara, S.; Yamada, A.; Kurokawa, K.; Uchida, S. Gene expression of vitamin D hydroxylase and megalin in the remnant kidney of nephrectomized rats. Kidney Int. 2003, 64, 414-420. [CrossRef] [PubMed]

28. Jacob, A.I.; Sallman, A.; Santiz, Z.; Hollis, B.W. Defective photoproduction of cholecalciferol in normal and uremic humans. J. Nutr. 1984, 114, 1313-1319. [PubMed]

29. Michaud, J.; Naud, J.; Ouimet, D.; Demers, C.; Petit, J.L.; Leblond, F.A.; et al. Reduced hepatic synthesis of calcidiol in uremia. J. Am. Soc. Nephrol. 2010, 21, 1488-1497. [CrossRef] [PubMed]

30. Kalousova, M.; Dusilova-Sulkova, S.; Zakiyanov, O.; Kostirova, M.; Safranek, R.; Tesar, V.; Zima, T. Vitamin D Binding Protein Is Not Involved in Vitamin D Deficiency in Patients with Chronic Kidney Disease. Biomed. Res. Int. 2015, 2015, 492365. [CrossRef] [PubMed]

31. De Boer, I.H.; Sachs, M.C.; Chonchol, M.; Himmelfarb, J.; Hoofnagle, A.N.; Ix, J.H.; Kremsdorf, R.A.; Lin, Y.S.; Mehrotra, R.; Robinson-Cohen, C.; et al. Estimated GFR and circulating 24,25-dihydroxyvitamin $\mathrm{D}_{3}$ concentration: A participant-level analysis of 5 cohort studies and clinical trials. Am. J. Kidney Dis. 2014, 64, 187-197. [CrossRef] [PubMed]

32. Mucsi, I.; Almasi, C.; Deak, G.; Marton, A.; Ambrus, C.; Berta, K.; Bonnardeaux, A.; Gascon-Barre, M.; Pichette, V. Serum 25(OH)-vitamin D levels and bone metabolism in patients on maintenance hemodialysis. Clin. Nephrol. 2005, 64, 288-294. [CrossRef] [PubMed]

33. Milinkovic, N.; Majkic-Singh, N.T.; Mirkovic, D.D.; Beletic, A.D.; Pejanovic, S.D.; Vujanic, S.T. Relation between 25(OH)-vitamin D deficiency and markers of bone formation and resorption in haemodialysis patients. Clin. Lab. 2009, 55, 333-339. [PubMed]

34. Lee, Y.H.; Kim, J.E.; Roh, Y.H.; Choi, H.R.; Rhee, Y.; Kang, D.R.; Lim, S.K. The combination of vitamin D deficiency and mild to moderate chronic kidney disease is associated with low bone mineral density and deteriorated femoral microarchitecture: Results from the KNHANES 2008-2011. J. Clin. Endocrinol. Metab. 2014, 99, 3879-3888. [CrossRef] [PubMed]

35. Bataille, S.; Landrier, J.F.; Astier, J.; Giaime, P.; Sampol, J.; Sichez, H.; Ollier, J.; Gugliotta, J.; Serveaux, M.; Cohen, J.; et al. The "Dose-Effect" Relationship Between 25-Hydroxyvitamin D and Muscle Strength in Hemodialysis Patients Favors a Normal Threshold of $30 \mathrm{ng} / \mathrm{mL}$ for Plasma 25-Hydroxyvitamin D. J. Ren. Nutr. 2016, 26, 45-52. [CrossRef] [PubMed] 
36. Boudville, N.; Inderjeeth, C.; Elder, G.J.; Glendenning, P. Association between 25-hydroxyvitamin D, somatic muscle weakness and falls risk in end-stage renal failure. Clin. Endocrinol. 2010, 73, 299-304. [CrossRef] [PubMed]

37. Ahmadi, F.; Damghani, S.; Lessan-Pezeshki, M.; Razeghi, E.; Maziar, S.; Mahdavi-Mazdeh, M. Association of low vitamin D levels with metabolic syndrome in hemodialysis patients. Hemodial. Int. 2016, 20, 261-269. [CrossRef] [PubMed]

38. Lai, S.; Coppola, B.; Dimko, M.; Galani, A.; Innico, G.; Frassetti, N.; Mariotti, A. Vitamin D deficiency, insulin resistance, and ventricular hypertrophy in the early stages of chronic kidney disease. Ren. Fail. 2014, 36, 58-64. [CrossRef] [PubMed]

39. Fusaro, M.; Gallieni, M.; Rebora, P.; Rizzo, M.A.; Luise, M.C.; Riva, H.; Bertoli, S.; Conte, F.; Stella, A.; Ondei, P. Atrial fibrillation and low vitamin D levels are associated with severe vascular calcifications in hemodialysis patients. J. Nephrol. 2016, 29, 419-426. [CrossRef] [PubMed]

40. Garcia-Canton, C.; Bosch, E.; Ramirez, A.; Gonzalez, Y.; Auyanet, I.; Guerra, R.; Perez, M.A.; Fernandez, E.; Toledo, A.; Lago, M. Vascular calcification and 25-hydroxyvitamin D levels in non-dialysis patients with chronic kidney disease stages 4 and 5. Nephrol. Dial. Transpl. 2010, 26, 2250-2256. [CrossRef] [PubMed]

41. London, G.M.; Guerin, A.P.; Verbeke, F.H.; Pannier, B.; Boutouyrie, P.; Marchais, S.J.; Metivier, F. Mineral Metabolism and Arterial Functions in End-Stage Renal Disease: Potential Role of 25-Hydroxyvitamin D Deficiency. J. Am. Soc. Nephrol. 2007, 18, 613-620. [CrossRef] [PubMed]

42. Liu, G.L.; Pi, H.C.; Hao, L.; Li, D.D.; Wu, Y.G.; Dong, J. Vitamin D Status Is an Independent Risk Factor for Global Cognitive Impairment in Peritoneal Dialysis Patients. PLoS ONE 2015, 10, e0143782. [CrossRef] [PubMed]

43. Ravani, P.; Malberti, F.; Tripepi, G.; Pecchini, P.; Cutrupi, S.; Pizzini, P.; Cutrupi, S.; Pizzini, P.; Mallamaci, F.; Zoccali, C. Vitamin D levels and patient outcome in chronic kidney disease. Kidney Int. 2009, 75, 88-95. [CrossRef] [PubMed]

44. Pilz, S.; Iodice, S.; Zittermann, A.; Grant, W.B.; Gandini, S. Vitamin D status and mortality risk in CKD: A meta-analysis of prospective studies. Am. J. Kidney Dis. 2011, 58, 374-382. [CrossRef] [PubMed]

45. Jean, G.; Lataillade, D.; Genet, L.; Legrand, E.; Kuentz, F.; Moreau-Gaudry, X.; Fouque, D. Impact of Hypovitaminosis D and Alfacalcidol Therapy on Survival of Hemodialysis Patients: Results from the French ARNOS Study. Nephron Clin. Pract. 2010, 118, c204-c210. [CrossRef] [PubMed]

46. Obi, Y.; Hamano, T.; Ichimaru, N.; Tomida, K.; Matsui, I.; Fujii, N.; Okumi, M.; Kaimori, J.Y.; Yazawa, K.; Kokado, Y.; et al. Vitamin D deficiency predicts decline in kidney allograft function: A prospective cohort study. J. Clin. Endocrinol. Metab. 2014, 99, 527-535. [CrossRef] [PubMed]

47. Bienaime, F.; Girard, D.; Anglicheau, D.; Canaud, G.; Souberbielle, J.C.; Kreis, H.; Noel, L.H.; Friedlander, G.; Elie, C.; Legendre, C.; et al. Vitamin D status and outcomes after renal transplantation. J. Am. Soc. Nephrol. 2013, 24, 831-841. [CrossRef] [PubMed]

48. Parikh, C.; Gutgarts, V.; Eisenberg, E.; Melamed, M.L. Vitamin D and Clinical Outcomes in Dialysis. Semin. Dial. 2015, 28, 604-609. [CrossRef] [PubMed]

49. Hu, M.C.; Shi, M.; Zhang, J.; Quinones, H.; Kuro-o, M.; Moe, O.W. Klotho deficiency is an early biomarker of renal ischemia-reperfusion injury and its replacement is protective. Kidney Int. 2010, 78, 1240-1251. [CrossRef] [PubMed]

50. Hu, M.C.; Shi, M.; Zhang, J.; Quinones, H.; Griffith, C.; Kuro-o, M.; Moe, O.W. Klotho deficiency causes vascular calcification in chronic kidney disease. J. Am. Soc. Nephrol. 2011, 22, 124-136. [CrossRef] [PubMed]

51. Li, Y.C. Renoprotective effects of vitamin D analogs. Kidney Int. 2010, 78, 134-139. [CrossRef] [PubMed]

52. Andrukhova, O.; Slavic, S.; Zeitz, U.; Riesen, S.C.; Heppelmann, M.S.; Ambrisko, T.D.; Markovic, M.; Kuebler, W.M.; Erben, R.G. Vitamin D is a regulator of endothelial nitric oxide synthase and arterial stiffness in mice. Mol. Endocrinol. 2014, 28, 53-64. [CrossRef] [PubMed]

53. Namir, Y.; Cohen, M.J.; Haviv, Y.S.; Slotki, I.; Shavit, L. Vitamin D levels, vitamin D supplementation, and prognosis in patients with chronic kidney disease. Clin. Nephrol. 2016, 86, 165-174. [CrossRef] [PubMed]

54. Kendrick, J.; Cheung, A.K.; Kaufman, J.S.; Greene, T.; Roberts, W.L.; Smits, G.; Chonchol, M. Associations of plasma 25-hydroxyvitamin D and 1,25-dihydroxyvitamin D concentrations with death and progression to maintenance dialysis in patients with advanced kidney disease. Am. J. Kidney Dis. 2012, 60, 567-575. [CrossRef] [PubMed] 
55. Nakano, C.; Hamano, T.; Fujii, N.; Obi, Y.; Matsui, I.; Tomida, K.; Mikami, S.; Inoue, K.; Shimomura, A.; Nagasawa, Y.; et al. Intact fibroblast growth factor 23 levels predict incident cardiovascular event before but not after the start of dialysis. Bone 2012, 50, 1266-1274. [CrossRef] [PubMed]

56. Massart, A.; Debelle, F.D.; Racape, J.; Gervy, C.; Husson, C.; Dhaene, M.; Wissing, K.M.; Nortier, J.L. Biochemical parameters after cholecalciferol repletion in hemodialysis: Results From the VitaDial randomized trial. Am. J. Kidney Dis. 2014, 64, 696-705. [CrossRef] [PubMed]

57. Ish-Shalom, S.; Segal, E.; Salganik, T.; Raz, B.; Bromberg, I.L.; Vieth, R. Comparison of daily, weekly, and monthly vitamin $\mathrm{D}_{3}$ in ethanol dosing protocols for two months in elderly hip fracture patients. J. Clin. Endocrinol. Metab. 2008, 93, 3430-3435. [CrossRef] [PubMed]

58. Mager, D.R.; Jackson, S.T.; Hoffmann, M.R.; Jindal, K.; Senior, P.A. Vitamin $\mathrm{D}_{3}$ supplementation, bone health and quality of life in adults with diabetes and chronic kidney disease: Results of an open label randomized clinical trial. Clin. Nutr. 2016. [CrossRef] [PubMed]

59. Jean, G.; Souberbielle, J.C.; Chazot, C. Monthly cholecalciferol administration in haemodialysis patients: A simple and efficient strategy for vitamin D supplementation. Nephrol. Dial. Transpl. 2009, 24, 3799-3805. [CrossRef] [PubMed]

60. Zitt, E.; Sprenger-Mahr, H.; Mundle, M.; Lhotta, K. Efficacy and safety of body weight-adapted oral cholecalciferol substitution in dialysis patients with vitamin D deficiency. BMC Nephrol. 2015, 16, 128. [CrossRef] [PubMed]

61. Delanaye, P.; Cavalier, E.; Fafin, C.; Dubois, B.E.; Krzesinski, J.M.; Moranne, O. Efficiency of delivery observed treatment in hemodialysis patients: The example of the native vitamin D therapy. J. Nephrol. 2016, 29, 99-103. [CrossRef] [PubMed]

62. Barros, X.; Rodriguez, N.Y.; Fuster, D.; Rodas, L.; Esforzado, N.; Mazza, A.; Rubello, D.; Campos, F.; Tapias, A.; Torregrosa, J.V. Comparison of two different vitamin D supplementation regimens with oral calcifediol in kidney transplant patients. J. Nephrol. 2016, 29, 703-709. [CrossRef] [PubMed]

63. Delanaye, P.; Weekers, L.; Warling, X.; Moonen, M.; Smelten, N.; Medart, L.; Krzesinski, J.M.; Cavalier, E. Cholecalciferol in haemodialysis patients: A randomized, double-blind, proof-of-concept and safety study. Nephrol. Dial. Transpl. 2013, 28, 1779-1786. [CrossRef] [PubMed]

64. Tokmak, F.; Quack, I.; Schieren, G.; Sellin, L.; Rattensperger, D.; Holland-Letz, T.; Weiner, S.M.; Rump, L.C. High-dose cholecalciferol to correct vitamin D deficiency in haemodialysis patients. Nephrol. Dial. Transpl. 2008, 23, 4016-4020. [CrossRef] [PubMed]

65. Courbebaisse, M.; Thervet, E.; Souberbielle, J.C.; Zuber, J.; Eladari, D.; Martinez, F.; Mamzer-Bruneel, M.F.; Urena, P.; Legendre, C.; Friedlander, G.; et al. Effects of vitamin D supplementation on the calcium-phosphate balance in renal transplant patients. Kidney Int. 2009, 75, 646-651. [CrossRef] [PubMed]

66. Martineau, A.R.; Jolliffe, D.A.; Hooper, R.L.; Greenberg, L.; Aloia, J.F.; Bergman, P.; Dubnov-Raz, G.; Esposito, S.; Ganmaa, D.; Ginde, A.A.; et al. Vitamin D supplementation to prevent acute respiratory tract infections: Systematic review and meta-analysis of individual participant data. BMJ 2017, 356, i6583. [CrossRef] [PubMed]

67. Hollis, B.W.; Wagner, C.L. Clinical review: The role of the parent compound vitamin D with respect to metabolism and function: Why clinical dose intervals can affect clinical outcomes. J. Clin. Endocrinol. Metab. 2013, 98, 4619-4628. [CrossRef] [PubMed]

68. Vieth, R. How to optimize vitamin D supplementation to prevent cancer, based on cellular adaptation and hydroxylase enzymology. Anticancer Res. 2009, 29, 3675-3684. [PubMed]

69. Bischoff-Ferrari, H.A.; Dawson-Hughes, B.; Staehelin, H.B.; Orav, J.E.; Stuck, A.E.; Theiler, R.; et al. Fall prevention with supplemental and active forms of vitamin D: A meta-analysis of randomised controlled trials. BMJ 2009, 339, b3692. [CrossRef] [PubMed]

70. Bischoff-Ferrari, H.A.; Willett, W.C.; Orav, E.J.; Lips, P.; Meunier, P.J.; Lyons, R.A.; Flicker, L.; Wark, J.; Jackson, R.D.; Cauley, J.A.; et al. A pooled analysis of vitamin D dose requirements for fracture prevention. N. Engl. J. Med. 2012, 367, 40-49. [CrossRef] [PubMed]

71. Sanders, K.M.; Stuart, A.L.; Williamson, E.J.; Simpson, J.A.; Kotowicz, M.A.; Young, D.; Nicholson, G.C. Annual high-dose oral vitamin $\mathrm{D}$ and falls and fractures in older women: A randomized controlled trial. JAMA 2010, 303, 1815-1822. [CrossRef] [PubMed] 
72. Bischoff-Ferrari, H.A.; Dawson-Hughes, B.; Orav, E.J.; Staehelin, H.B.; Meyer, O.W.; Theiler, R.; Dick, W.; Willett, W.C.; Egli, A. Monthly High-Dose Vitamin D Treatment for the Prevention of Functional Decline: A Randomized Clinical Trial. JAMA Intern. Med. 2016, 176, 175-183. [CrossRef] [PubMed]

73. Bischoff-Ferrari, H.A.; Dawson-Hughes, B.; Platz, A.; Orav, E.J.; Stahelin, H.B.; Willett, W.C.; Can, U.; Egli, A.; Mueller, N.J.; Looser, S.; et al. Effect of high-dosage cholecalciferol and extended physiotherapy on complications after hip fracture: A randomized controlled trial. Arch. Intern. Med. 2010, 170, 813-820. [CrossRef] [PubMed]

74. Kandula, P.; Dobre, M.; Schold, J.D.; Schreiber, M.J., Jr.; Mehrotra, R.; Navaneethan, S.D. Vitamin D supplementation in chronic kidney disease: A systematic review and meta-analysis of observational studies and randomized controlled trials. Clin J. Am. Soc. Nephrol. 2011, 6, 50-62. [CrossRef] [PubMed]

75. Alvarez, J.A.; Law, J.; Coakley, K.E.; Zughaier, S.M.; Hao, L.; Shahid Salles, K.; Wasse, H.; Gutierrez, O.M.; Ziegler, T.R.; Tangpricha, V. High-dose cholecalciferol reduces parathyroid hormone in patients with early chronic kidney disease: A pilot, randomized, double-blind, placebo-controlled trial. Am. J. Clin. Nutr. 2012, 96, 672-679. [CrossRef] [PubMed]

76. Cupisti, A.; Vigo, V.; Baronti, M.E.; D'Alessandro, C.; Ghiadoni, L.; Egidi, M.F. Vitamin D status and cholecalciferol supplementation in chronic kidney disease patients: An Italian cohort report. Int. J. Nephrol. Renovasc. Dis. 2015, 8, 151-157. [CrossRef] [PubMed]

77. Jean, G.; Vanel, T.; Terrat, J.C.; Chazot, C. Prevention of secondary hyperparathyroidism in hemodialysis patients: The key role of native vitamin D supplementation. Hemodial. Int. 2010, 14, 486-491. [CrossRef] [PubMed]

78. Sprague, S.M.; Silva, A.L.; Al-Saghir, F.; Damle, R.; Tabash, S.P.; Petkovich, M.; Messner, E.J.; White, J.A.; Melnick, J.Z.; Bishop, C.W. Modified-release calcifediol effectively controls secondary hyperparathyroidism associated with vitamin D insufficiency in chronic kidney disease. Am J. Nephrol. 2014, 40, 535-545. [CrossRef] [PubMed]

79. Bhan, I.; Dobens, D.; Tamez, H.; Deferio, J.J.; Li, Y.C.; Warren, H.S.; Ankers, E.; Wenger, J.; Tucker, J.K.; Trottier, C.; et al. Nutritional vitamin D supplementation in dialysis: A randomized trial. Clin J. Am. Soc. Nephrol. 2015, 10, 611-619. [CrossRef] [PubMed]

80. Tangpricha, V.; Wasse, H. Vitamin D therapy in kidney disease: More vitamin D is necessary. Am. J. Kidney Dis. 2014, 64, 667-669. [CrossRef] [PubMed]

81. Seibert, E.; Heine, G.H.; Ulrich, C.; Seiler, S.; Kohler, H.; Girndt, M. Influence of cholecalciferol supplementation in hemodialysis patients on monocyte subsets: A randomized, double-blind, placebo-controlled clinical trial. Nephron Clin. Pract. 2013, 123, 209-219. [CrossRef] [PubMed]

82. Kim, M.J.; Frankel, A.H.; Donaldson, M.; Darch, S.J.; Pusey, C.D.; Hill, P.D.; Mayr, M.; Tam, F.W. Oral cholecalciferol decreases albuminuria and urinary TGF- $\beta 1$ in patients with type 2 diabetic nephropathy on established renin-angiotensin-aldosterone system inhibition. Kidney Int. 2011, 80, 851-860. [CrossRef] [PubMed]

83. Aytac, M.B.; Deveci, M.; Bek, K.; Kayabey, O.; Ekinci, Z. Effect of cholecalciferol on local arterial stiffness and endothelial dysfunction in children with chronic kidney disease. Pediatr. Nephrol. 2016, 31, $267-277$. [CrossRef] [PubMed]

84. Meireles, M.S.; Kamimura, M.A.; Dalboni, M.A.; Giffoni de Carvalho, J.T.; Aoike, D.T.; Cuppari, L. Effect of cholecalciferol on vitamin D-regulatory proteins in monocytes and on inflammatory markers in dialysis patients: A randomized controlled trial. Clin. Nutr. 2016, 35, 1251-1258. [CrossRef] [PubMed]

85. Karakas, Y.; Sahin, G.; Urfali, F.E.; Bal, C.; Degirmenci, N.A.; Sirmagul, B. Effect of vitamin D supplementation on endothelial dysfunction in hemodialysis patients. Hemodial. Int. 2017, 21, 97-106. [CrossRef] [PubMed]

86. Mann, M.C.; Hobbs, A.J.; Hemmelgarn, B.R.; Roberts, D.J.; Ahmed, S.B.; Rabi, D.M. Effect of oral vitamin $\mathrm{D}$ analogs on mortality and cardiovascular outcomes among adults with chronic kidney disease: A meta-analysis. Clin. Kidney J. 2015, 8, 41-48. [CrossRef] [PubMed]

87. Levin, G.P.; Robinson-Cohen, C.; de Boer, I.H.; Houston, D.K.; Lohman, K.; Liu, Y.; Kritchevsky, S.B.; Cauley, J.A.; Tanaka, T.; Ferrucci, L.; et al. Genetic variants and associations of 25-hydroxyvitamin D concentrations with major clinical outcomes. JAMA 2012, 308, 1898-1905. [CrossRef] [PubMed]

88. Vieth, R. The mechanisms of vitamin D toxicity. Bone Miner. 1990, 11, 267-272. [CrossRef]

89. Vieth, R. Vitamin D supplementation, 25-hydroxyvitamin D concentrations, and safety. Am. J. Clin. Nutr. 1999, 69, 842-856. [PubMed] 
90. Jacobus, C.H.; Holick, M.F.; Shao, Q.; Chen, T.C.; Holm, I.A.; Kolodny, J.M.; Fuleihan, G.E.; Seely, E.W. Hypervitaminosis D associated with drinking milk. N. Engl. J. Med. 1992, 326, 1173-1177. [CrossRef] [PubMed]

91. Cavalier, E.; Wallace, A.M.; Knox, S.; Mistretta, V.I.; Cormier, C.; Souberbielle, J.C. Serum vitamin D measurement may not reflect what you give to your patients. J. Bone Miner. Res. 2008, 23, 1864-1865. [CrossRef] [PubMed]

92. Armas, L.A.; Hollis, B.W.; Heaney, R.P. Vitamin $\mathrm{D}_{2}$ is much less effective than vitamin $\mathrm{D}_{3}$ in humans. J. Clin. Endocrinol. Metab. 2004, 89, 5387-5391. [CrossRef] [PubMed]

93. Holick, M.F.; Biancuzzo, R.M.; Chen, T.C.; Klein, E.K.; Young, A.; Bibuld, D.; Reitz, R.; Salameh, W.; Ameri, A.; Tannenbaum, A.D. Vitamin D2 is as effective as vitamin $\mathrm{D}_{3}$ in maintaining circulating concentrations of 25-hydroxyvitamin D. J. Clini. Endocrinol. Metab. 2008, 93, 677-681. [CrossRef] [PubMed]

94. Oliveri, B.; Mastaglia, S.R.; Brito, G.M.; Seijo, M.; Keller, G.A.; Somoza, J.; Diez, R.A.; Di Girolamo, G. Vitamin D3 seems more appropriate than D2 to sustain adequate levels of 25OHD: A pharmacokinetic approach. Eur. J. Clin. Nutr. 2015, 69, 697-702. [CrossRef] [PubMed]

95. Wetmore, J.B.; Kimber, C.; Mahnken, J.D.; Stubbs, J.R. Cholecalciferol v. ergocalciferol for 25-hydroxyvitamin $\mathrm{D}(25(\mathrm{OH}) \mathrm{D})$ repletion in chronic kidney disease: A randomised clinical trial. Br. J. Nutr. 2016, 116, 2074-2081. [CrossRef] [PubMed]

96. Lehmann, U.; Hirche, F.; Stangl, G.I.; Hinz, K.; Westphal, S.; Dierkes, J. Bioavailability of vitamin D(2) and $\mathrm{D}(3)$ in healthy volunteers, a randomized placebo-controlled trial. J. Clini. Endocrinol. Metab. 2013, 98, 4339-4345. [CrossRef] [PubMed]

97. Berl, T.; Berns, A.S.; Hufer, W.E.; Hammill, K.; Alfrey, A.C.; Arnaud, C.D.; et al. 1,25 dihydroxycholecalciferol effects in chronic dialysis. A double-blind controlled study. Ann. Intern. Med. 1978, 88, 774-780. [CrossRef] [PubMed]

98. Lessard, M.; Ouimet, D.; Leblanc, M.; Nadeau-Fredette, A.C.; Bell, R.; Lafrance, J.P.; Schrier, R.W. Comparison of oral and intravenous alfacalcidol in chronic hemodialysis patients. BMC Nephrol. 2014, 15, 27. [CrossRef] [PubMed]

99. Urena, P.; Jacobson, S.H.; Zitt, E.; Vervloet, M.; Malberti, F.; Ashman, N.; Leavey, S.; Rix, M.; Os, I.; Saha, H.; et al. Cinacalcet and achievement of the NKF/K-DOQITM recommended target values for bone and mineral metabolism in real-world clinical practice-the ECHO observational study. Nephrol. Dial. Transpl. 2009, 24, 2852-2859. [CrossRef] [PubMed]

100. Kalantar-Zadeh, K.; Kuwae, N.; Regidor, D.L.; Kovesdy, C.P.; Kilpatrick, R.D.; Shinaberger, C.S.; McAllister, C.J.; Budoff, M.J.; Salusky, I.B.; Kopple, J.D. Survival predictability of time-varying indicators of bone disease in maintenance hemodialysis patients. Kidney Int. 2006, 70, 771-780. [CrossRef] [PubMed]

101. Melamed, M.L.; Eustace, J.A.; Plantinga, L.; Jaar, B.G.; Fink, N.E.; Coresh, J.; Klag, M.J.; Powe, N.R. Changes in serum calcium, phosphate, and PTH and the risk of death in incident dialysis patients: A longitudinal study. Kidney Int. 2006, 70, 351-357. [CrossRef] [PubMed]

102. Teng, M.; Wolf, M.; Lowrie, E.; Ofsthun, N.; Lazarus, J.M.; Thadhani, R. Survival of patients undergoing hemodialysis with paricalcitol or calcitriol therapy. N. Engl. J. Med. 2003, 349, 446-456. [CrossRef] [PubMed]

103. Tentori, F.; Hunt, W.C.; Stidley, C.A.; Rohrscheib, M.R.; Bedrick, E.J.; Meyer, K.B.; Johnson, H.K.; Zager, P.G. Mortality risk among hemodialysis patients receiving different vitamin D analogs. Kidney Int. 2006, 70, 1858-1865. [CrossRef] [PubMed]

104. Zheng, Z.; Shi, H.; Jia, J.; Li, D.; Lin, S. Vitamin D supplementation and mortality risk in chronic kidney disease: A meta-analysis of 20 observational studies. BMC Nephrol. 2013, 25, 199. [CrossRef] [PubMed]

105. Shoji, T.; Shinohara, K.; Kimoto, E.; Emoto, M.; Tahara, H.; Koyama, H.; Inaba, M.; Fukumoto, S.; Ishimura, E.; Miki, T. Lower risk for cardiovascular mortality in oral 1alpha-hydroxy vitamin $\mathrm{D}_{3}$ users in a haemodialysis population. Nephrol. Dial. Transpl. 2004, 19, 179-184. [CrossRef]

106. Tanaka, S.; Ninomiya, T.; Taniguchi, M.; Fujisaki, K.; Tokumoto, M.; Hirakata, H.; Ooboshi, H.; Kitazono, T.; Tsuruya, K. Comparison of oral versus intravenous vitamin D receptor activator in reducing infection-related mortality in hemodialysis patients: The Q-Cohort Study. Nephrol. Dial. Transpl. 2016, 31, 1152-1160. [CrossRef] [PubMed]

107. Li, X.H.; Feng, L.; Yang, Z.H.; Liao, Y.H. The Effect of Active Vitamin D on Cardiovascular Outcomes in Predialysis Chronic Kidney Diseases: A Systematic Review and Meta-Analysis. Nephrology 2015, 20, 706-714. [CrossRef] [PubMed] 
108. Inaguma, D.; Tanaka, A.; Shinjo, H.; Kato, A.; Murata, M. Predialysis Vitamin D Receptor Activator Treatment and Cardiovascular Events after Dialysis Initiation: A Multicenter Observational Study. Nephron 2016, 133, 35-43. [CrossRef] [PubMed]

109. Hansen, D.; Rasmussen, K.; Danielsen, H.; Meyer-Hofmann, H.; Bacevicius, E.; Lauridsen, T.G.; Madsen, J.K.; Tougaard, B.G.; Marckmann, P.; Thye-Roenn, P.; et al. No difference between alfacalcidol and paricalcitol in the treatment of secondary hyperparathyroidism in hemodialysis patients: A randomized crossover trial. Kidney Int. 2011, 80, 841-850. [CrossRef] [PubMed]

110. Dusilova-Sulkova, S.; Safranek, R.; Vavrova, J.; Horacek, J.; Pavlikova, L.; Palicka, V. Low-dose cholecalciferol supplementation and dual vitamin D therapy in haemodialysis patients. Int. Urol. Nephrol. 2015, 47, 169-176. [CrossRef] [PubMed]

111. Lou, Y.R.; Molnar, F.; Perakyla, M.; Qiao, S.; Kalueff, A.V.; St-Arnaud, R.; Carlberg, C.; Tuohimaa, P. 25-Hydroxyvitamin $\mathrm{D}(3)$ is an agonistic vitamin D receptor ligand. J. Steroid Biochem. Mol. Biol. 2010, 118, 162-170. [CrossRef] [PubMed]

112. Arcidiacono, M.V.; Yang, J.; Fernandez, E.; Dusso, A. The induction of C/EBP $\beta$ contributes to vitamin D inhibition of ADAM17 expression and parathyroid hyperplasia in kidney disease. Nephrol. Dial. Transpl. 2015, 30, 423-433. [CrossRef] [PubMed]

113. Agarwal, R.; Georgianos, P.I. Con: Nutritional vitamin D replacement in chronic kidney disease and end-stage renal disease. Nephrol. Dial. Transpl. 2016, 31, 706-713. [CrossRef] [PubMed]

114. Zoccali, C.; Mallamaci, F. Moderator's view: Vitamin D deficiency treatment in advanced chronic kidney disease: A close look at the emperor's clothes. Nephrol. Dial. Transpl. 2016, 31, 714-716. [CrossRef] [PubMed]

(C) 2017 by the authors. Licensee MDPI, Basel, Switzerland. This article is an open access article distributed under the terms and conditions of the Creative Commons Attribution (CC BY) license (http:/ / creativecommons.org/licenses/by/4.0/). 